Philosophy and Progress: Vols. LV-LVI, January-June, July-December, 2014 ISSN 1607-2278 (Print), DOI : http://dx.doi.org/10.3329/pp.v55i1-2.26397

\section{ASSESSMENT OF CONSUMERS' LOYALTY AND SWITCHING BEHAVIOR: A STUDY ON SELECTED TEA BRANDS IN BANGLADESH}

\section{Shahpar Shams*}

\begin{abstract}
Rivalry has become more drastic among diverse companies since it is the era of global marketing now. In order to grasp the best opportunity from the marketplace, marketers now-a-days adopt multifarious strategies to ensure their triumph in the long run. To do so, building and maintaining customer loyalty has become the best option for marketers. Tea marketers in Bangladesh, likewise marketers of other consumer goods, have been facing fierce competition as demand for this drink has been increased. As such, they have also been adopting this technique to ensure their sustainable growth and market holdings. Here, bringing down consumers' expectation and perception in the single point is a great challenge for a marketer which is prerequisite to customer
\end{abstract}

\footnotetext{
* Lecturer, Department of Business Administration, East West University, Dhaka, Email: shahparshams@gmail.com
}

satisfaction. In this study, the researcher attempted to work out with attributes those consumers expect in a branded tea and presence of which might create consumers' positive perception towards the brand and how this positive perception works for turning to be loyal. In addition to, when positive perception does not work, how consumers switch to other brand for meeting up their expectations. In this context, the researcher has collected direct data from the consumers to understand their views.

Key Words: Loyalty, Switching behavior, Tea Brand.

\section{0: INTRODUCTION}

Tea is one of the most important non-alcoholic beverage worldwide and has been gaining further popularity as an important 'health drink' in view of its purported medicinal value. It is served as morning drink for nearly $2 / 3^{\text {rd }}$ of the world population daily. The Bangladesh tea industry is one of the major sources of income for the national exchequer (Islam, Iqbal, Quddus, and Ali, 2009).

The consumption of tea in our domestic market is 43 million $\mathrm{kg}$ per year. Brand packet tea consumers are $68.8 \%$ of total tea consumers in Bangladesh (Kaniz, 2009). Consumers are aware enough to purchase tea and thus consider many things while purchasing tea brands. In last 10 years, more than 10 nationally and locally recognized brands have been launched in domestic market e.g. Ispahani, Seylon, Lipton Taaza, HRC, Finley, Tetly, Kazi and Kazi, Pran etc.

The market scenario itself speaks the competitive situation in the industry. Existing companies in this industry are very conscious to fulfill needs of the consumers. As there are many quality brands exist in the market, consumers have choices to select a premium brand with desired quality. Therefore, there is furious competition among existing companies to increase 
loyal customer base and reduce volume of switching over another brand to build a profitable long term relationship with them.

This study attempted to know about consumers' trend to be loyal towards a particular tea brand. Marketers of branded tea could understand importance of consumers' brand loyalty and tendency of switching over other brands. They could also have an idea about which factors are important to build consumer loyalty and what are the reasons that might cause to switch a brand. Government and also policy makers can feel the demand of this sector and might take steps to improve this sector by implementing different policies.

\section{1: Statement of the Problem}

To identify consumers' loyalty toward a particular tea brand and their switching behavior over other tea brands, with respect to factors that influence tea consumption.

\section{2: Objectives of the study}

Broad Objective: This study was attempted to identify consumers' loyalty to a particular brand and switching possibilities to another tea brand.

Some specific objectives of this study are:

$>$ Which factors (price, availability, taste, aroma, package, and image) of tea lead consumers to repurchase a branded tea.

$>$ Whether consumers have long term relationship with a particular brand.

$>$ Whether consumers can recall the name of a particular tea brand at first catch while purchasing tea.

$>$ Reasons for switching current brand of tea.

\section{0: RESEARCH QUESTIONS AND RESEARCH HYPOTHESES}

\section{1: Research Questions}

This study has identified following questions:

Q 1. Which factors of a particular brand of tea lead them to repurchase which later contribute to become loyal?

Q 2. Whether consumers' have long term relationship with a brand of tea?

Q 3. Could consumers' recall the name of the brand at first chance while purchasing tea?

Q 4. Do consumers' perceived quality match with their expectation?

Q 5. How many consumers might switch their current brand?

\section{2: Research Hypotheses}

For this study following hypotheses can be developed:

$\mathrm{H}_{0}$ 1: Taste does not have positive and significant relationship with consumers' loyalty.

$\mathrm{H}_{1}$ 1: Taste has positive and significant relationship with consumers' loyalty.

$\mathrm{H}_{0}$ 2: Color of tea does not have positive and significant relationship with consumers' loyalty.

$\mathrm{H}_{2}$ 2: Color of tea has positive and significant relationship with consumers' loyalty.

$\mathrm{H}_{0}$ 3: Aroma does not have positive and significant relationship with consumers' loyalty.

$\mathrm{H}_{3}$ 3: Aroma has positive and significant relationship with customer loyalty.

$\mathrm{H}_{0}$ 4: Quality does not have positive and significant relationship with consumers' loyalty. 
$\mathrm{H}_{4} 4$ : Quality has positive and significant relationship with consumers' loyalty.

$\mathrm{H}_{0}$ 5: Price does not have positive and significant relationship with consumers' loyalty.

$\mathrm{H}_{5}$ 5: Price has positive and significant relationship with consumers' loyalty.

$\mathrm{H}_{0}$ 6: Brand recall does not have positive and significant relationship with consumers' loyalty.

$\mathrm{H}_{6}$ 6: Brand recall has positive and significant relationship with consumers' loyalty.

$\mathrm{H}_{0}$ 7: Consumers do not refer others to purchase his/her preferred brand of Tea.

$\mathrm{H}_{7}$ 7: Consumers refer others to purchase his/her preferred brand of Tea.

\section{0: LITERATURE REVIEW}

In Bangladesh, tea industry contributes largely as a major source of income for the national exchequer. The country occupies the $9^{\text {th }}$ position in respect of production among the 30 tea producing countries of the world. Half of the produced tea is consumed at home and the rest is exported (Islam et. al., 2009). In the local market, consumers have many choices of brands to opt a desired brand. Hence, tea marketers are fighting for capturing consumers' loyalty by meeting consumers' expectations related to product i.e., quality of tea, packaging, and other benefits of the product. Improvement in quality and consistency in quality are also expected by tea consumers. In respect to quality of tea, granules are very important. Consumers want granules that are of medium size. They prefer no adulteration, rather same size. Absence of dust tea with granules is also very important. Besides, fresh smell and aroma of tea leaves, blackish color and fresh- free flowing dry grains, reasonable price are important to meet-up tea drinkers' expectation. High availability can save their time and efforts. Accurate weight that is written on pack and ease of preparation are other expectations of consumers. In case of packaging, airtight pack is wanted by tea users because it keeps tea fresh. Besides, presence of expiry and manufacture date on pack and Bangladesh Standards And Testing Institution seal on pack can make consumers feel safe about the product. Consumers expect a good combination of all these when they purchase tea from the market (SIRIUS, 2009).

Different consumers have different perception regarding tea. Good color of liquor-dark brown color for milk tea and reddish color for raw tea is necessary for a good cup of tea. Spread out of aroma while brewing and good aroma from end cup like fresh tea leaves is liked by all. People usually also prefer following attributes in tea-milk and sugar need to be dissolved properly, there should be no dust in end cup, taste of tea should not be bitter, ease of preparation of tea (preferred by busy people). It was found that people also drink tea to prevent disease such as, cold and headache problem, to remove fatigue, tiredness, and loneliness and to relax the brain. It is also good for guest entertainment and essential in case of gossiping. Researchers also found that consumers carry on different expectations regarding attributes of different tea brands which they want to receive while they having it. They have different requirement regarding their desired need, perceived quality, perceived value, expectation, and brand image.

When consumers' perception matches with the expectation, consumers get satisfaction and consequently satisfied consumers repurchase the brand and may become loyal towards the brand if their desire is almost meet-up by the particular brand. Moreover, adequate after sales service and proper problem solving attitude of the company can build loyal consumers. When consumers' perceptions do not match with 
their expectation they become dissatisfied and sometimes tend to switch the brand. Consumers may be disappointed when they require more amount of tea leaves for preparing tea gives users a thought of wastage of tea and poor quality. Bad flavor after opening pack or in end cup is always unwanted by the consumers. Blackish color of liquor is not liked by all. Bitter taste, sticky granules, mix of dust tea in leaf tea, presence of dust in end cup cannot make consumers satisfied. Moreover, inconsistent quality causes dissatisfaction. Excessive increase of price and less availability cause to switch the current brand. Attractive promotional offers of other brands such as, attractive gifts or discount could also encourage trying another brand. Consumers can be dissatisfied with all these or with few of these factors and may switch the brand. (SIRIUS, 2009).

It is widely accepted among researchers that customer satisfaction is a strong predictor of behavioral variables such as repurchases intentions and loyalty. According to many researchers companies should try to hold loyal consumers to build a strong customer base. The old rules of successful and profitable management still hold good: customer retention is still a key to long-term profits, while on the other side of the coin there is a high cost-penalty to low loyalty. Indeed, the very fact that customers can so readily assess the competing services and products on offer and then so easily make the new purchase does in itself give added weight to the importance of building strong ties of loyalty with customers. Long term customer retention in competitive markets requires the supplier to go beyond mere basic satisfaction and to look for ways of establishing ties of loyalty that will help ward off competitor attack.

It makes sense to look at customer loyalty directly, simply because it reflects what happens in real life. Assessment goes beyond just physical and tangible features but also includes emotional and psychological rewards such as assurance of reliability, perceptions of having made a wise choice, admiration from friends and colleagues, and so on. The corollary is that customer retention leads to greater long-term profitability which results in loyalty-that is not just behavior but also of commitment and belief (Clarke, 2001).

It was found that in order to increase the loyalty of own customers, companies need to minimize the gap between customers and own brand and to maximize the gap between own brand and competing brand. If the company cannot make the own brand differentiated from the competing brand, the ultimate result will be less gap between own brand to the competing one and consumers might switch.

Customer switching behavior is consequently a serious threat to the firms that needs to be monitored carefully in order to go through the processes of determining customers' switching decisions (Lopez et. al., 2008). Consumers' switching decision is based upon: the cost of the decision, the perceived benefits of any such decision, and a customer's relative assessment of other factors (Watson et. al., 2002). When a customer switches to other brand, a company not only loses him/her but also loses previous investment made over the customer and needs to invest again on persuading a new customer. Researchers also found that a firm needs to invest resources in attracting new customers to replace the ones it has lost (advertising, promotion, initial discounts), which can cost five times more to acquire a new customer than to retain an old one. Consequently, retaining the current customer base is much more attractive than searching for new customers. Furthermore, the consequences that losing a customer can have for the firm (negative word-of-mouth, damage on brand image, reputation) are expected to have a harmful impact on the firm's future prospects and could reduce the firm's chances of acquiring new 
customers at later stages, or raise the costs of doing so (Lopez et. al., 2008).

Recent researchers tried to establish the bases for improving the understanding of customers' switching behavior and can be articulated in three main areas: (a) the processes of underlying customer switching decisions; (b) the specific factors that motivate switching; and (c) the heterogeneous nature of the firms' customer base and its relevance in order to analyze the differences between switchers and continuers (Lopez et. al., 2008). Researchers in this study, was guided by these factors to find out reasons for switching over different tea brands by consumers.

In order to take steps to stop switching by consumers, companies should attempt to find out ways to proactively understand what their consumers really desire and build up a strong long term relationship with them by building brand equity. According to Kevin Lane Keller (2008), building brand equity needs a brand to be a perfect blend of rational fact and emotional attachment, measured in terms of performance characteristics and imagery. Customers' relationship to a brand can be plotted in terms of their attitudes on the pyramid of engagement and their relative bias towards a rationally dominant or emotionally dominant relationship. Therefore, in this study, Kevin Lane Keller's branding block (figure-2) was used to identify different factors that develop consumers' relationship with the brand from brand salience to brand resonance if the factors contribute in a positive manner.
Figure -1: Sub-dimensions of Brand Building Blocks

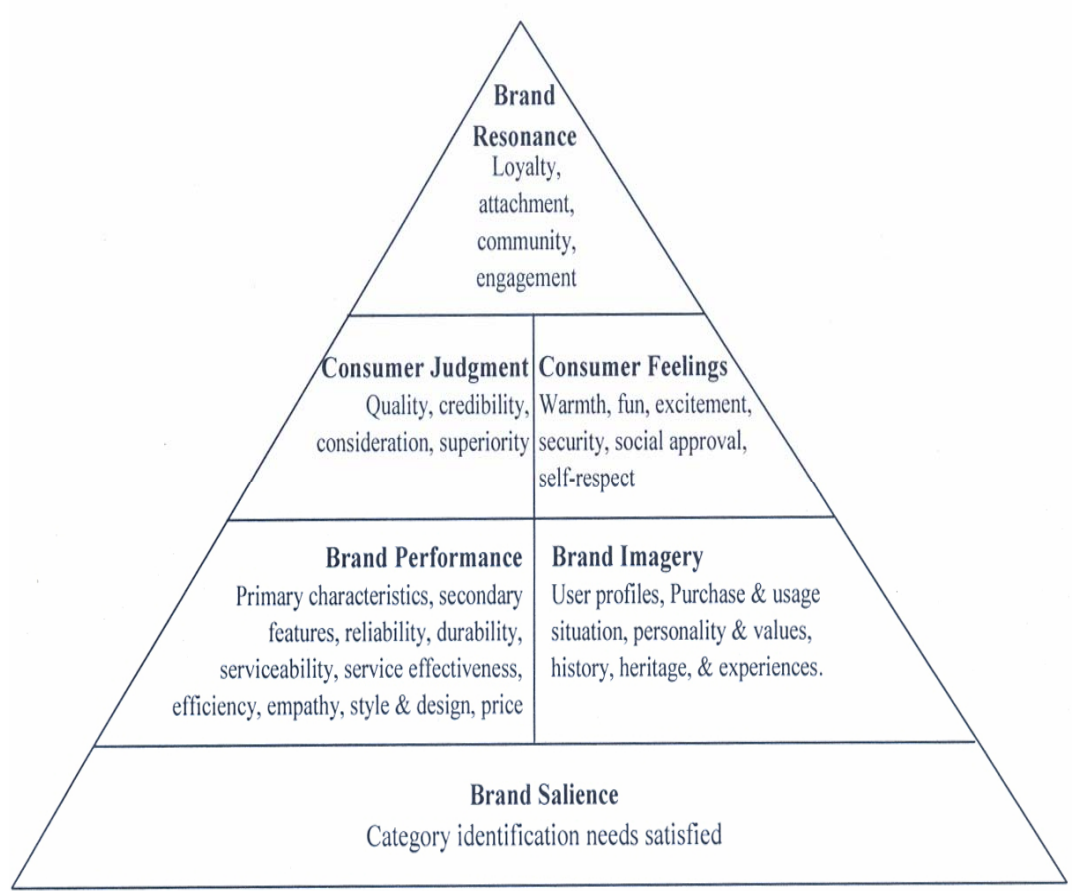

Source: Adopted from Kevin Lane Keller' Customer-Based Brand Equity Pyramid,

$$
\text { (pp.258, 2001.) }
$$

In order to identify consumers' loyalty of a particular tea brand, the factors in this model were required to measure. After measuring these factors, consumers' bonding to a particular tea brand was identified by using Brown's Brand Dynamics (Figure-3). In this approach, five steps were depicted describing customers' loyalty base. 


\section{Figure- 2: Brand Dynamics}

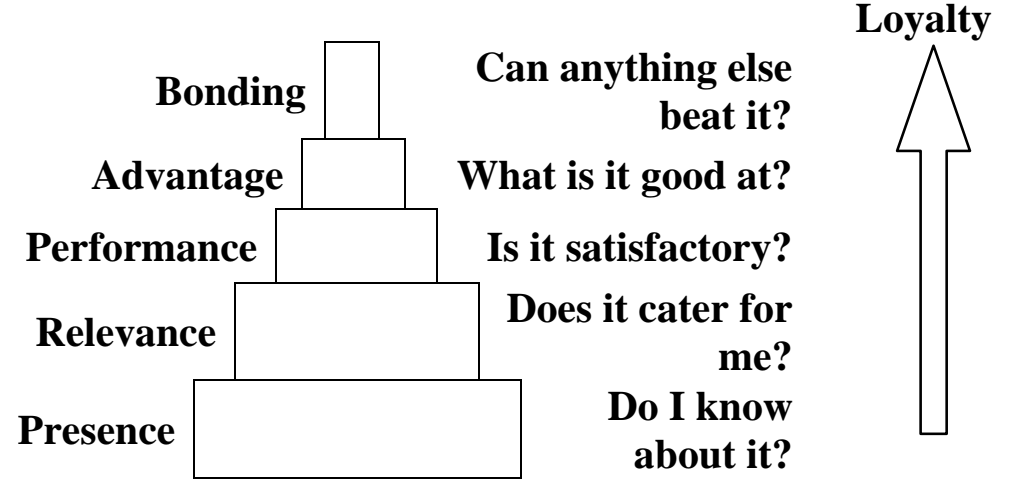

\section{Source: Adopted from Millward Brown's} BrandDynamics $^{\mathrm{TM}}$. (pp.257, 2001.)

This figure step by step indicates increase of consumers' loyalty toward a brand. When consumers know about a brand then he/she is in presence stage. Then simultaneously if the brand caters for him/her, satisfy him/her, gives advantage then he/she reaches at bonding stage, where he/she has a strong bonding with that brand.

\section{0: THEORETICAL FRAMEWORK}

Researchers of this study attempted to asses consumers' loyalty toward a specific tea brand by measuring consumers' relationship and bonding with that brand. Consumers' need of drinking tea, expectations, perceived value, perceived quality, image of brand in the eyes and mind of the consumer, product attributes were considered important factors that might derive satisfaction that consequently may cause to become loyal toward a brand. In order to measure satisfaction or dissatisfaction level that might cause to become loyal toward a brand or to switch to other brand (if dissatisfaction is in force), researchers used the following framework in this study:

Figure-3: Factors Affecting Consumers' Loyalty and Switching Behavior

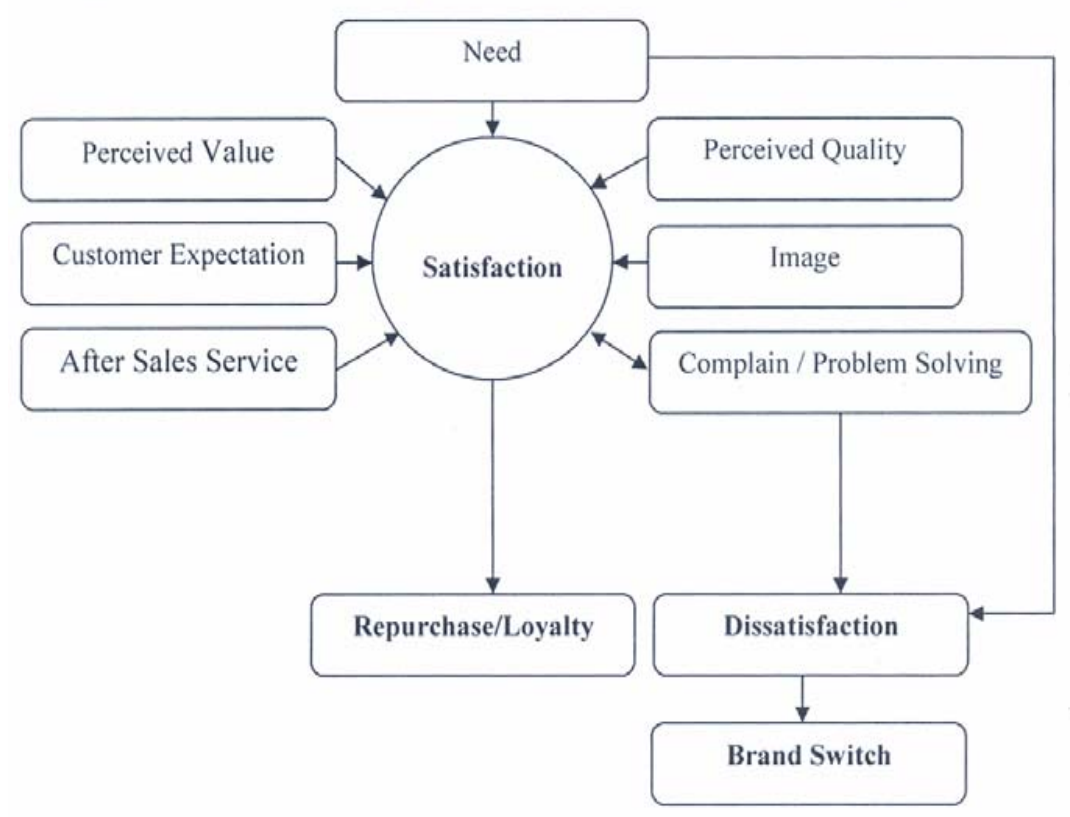

Source: Developed by author

Different consumers have different needs, different expectation regarding perceived value, quality, brand image, after sales service, complaints and problem solving attitude toward a brand. When all these factors or any one or two of them matches with their perception then they might get satisfied and tend to repurchase the product and may also become loyal accordingly. On the other hand, if all these factors or any one or two important factors do not match with their perception then they might become dissatisfied and might also switch to other brand. 


\section{0: METHODOLOGY}

In this study, researchers conducted a qualitative research to properly identify the problem by using secondary data from different sources i.e. information from various publications, marketing related journals etc. After, getting an in-depth view of the problem, a descriptive research was conducted to find out factors that affect consumers' loyalty and switching behavior. In this regard, several factors like need for drinking tea, expectations, perceived quality, perceived value, problem solving tendency of the companies as per consumers' desire, image of a specific tea brand in consumers' eyes and mind, were needed to measure consumers' satisfaction/dissatisfaction toward a brand, and consequently which factors might drive consumers to be loyal to a brand or switch to other brands. In order to pursue consumers' relationship with a specific brand (satisfaction level to measure loyalty; otherwise dissatisfaction level that might incite switching behavior), these aforementioned factors were also examined to look for whether they contribute in a positive manner. To measure customers' loyalty base with a brand, customers bonding to a brand was also required to determine. For this purpose, primary data was collected from different target group of tea drinkers.

Researchers of this study collected quantitative data from the customers of tea through a survey. As the study was attempted to identify the factors that drive consumers' loyalty to a specific tea brand or switching behavior, the strength of relationship between the identified factors and consumers' loyalty was needed to examine. In order to examine the associative relationship, multiple regression analysis has been used and thus one dependent variable and multiple independent variables were required. To conduct multiple regression analysis, metric scaled (interval or ratio scaled) data on dependent and independent variables was required. Therefore, a non-comparative scaling technique (see detail in scaling technique) was applied in this study. A questionnaire using 7 point likert scale was designed to collect data from 120 respondents.

For the purpose of analysis, multiple regression analysis has been used to determine the strength of relationship between the dependent variable and one or more independent variables (Malhotra, 2008, p.552). Finally, cross tabulation was also used in order to understand male or female consumers' switching possibilities over different tea brands.

\section{1: Research Design}

In this study, descriptive research design was adopted to describe salient factors and product features that influence consumers' loyalty and switching behavior. Thus, specific hypotheses were tested to examine the relationships among different variables (expectations, perceived quality, perceived value, problem solving tendency of the companies and others). Findings of this study will be helpful for tea marketers in the form of input into decision making regarding building strong loyal customer base. This might also be helpful to avoid cost to loss existing customers.

\section{2: Information needs for the study}

Information on consumers' expectations, perceived quality, perceived value, problem solving tendency of companies and product attributes and reasons for consumers' switching behavior were required for this study. Information regarding consumers' attachment to a brand, feelings and judgment regarding a brand, and image and performance of a brand were also required. Personal interview technique was used to gather data from tea. 


\section{3: Data collection}

Consumers' opinion regarding their expectations, perception, perceived value, image of a brand, overall feelings and judgment regarding a brand was collected through a survey. In addition to this, researchers also collected data through several previous research works, web information, and several journals and magazines.

\section{4: Scaling Techniques}

In order to measure consumers' loyalty to a branded tea, the relevant characteristics of consumers were needed to determine. Therefore, measurement of those characteristics of the objects was required. In order to measure the characteristics of the objects, it was required to measure the dependent and independent variables. It was needed to measure the variables on metric scale as this study attempted to examine the strength of relationship between independent and dependent variables (using multiple regression). So, non-comparative scaling technique was applied to collect metric scaled data. Respondents evaluated only one object at a time and rated the variables on 7 point likert scale (itemized rating scale).

\section{5: Questionnaire development}

For this study, the questionnaire was formed having the options for both the consumers and non consumers of tea to collect their different opinions towards tea brands. The questions were formed on 7 point likert scale to gather data related to loyalty level and perceived value level. There were open ended questions for identifying users and non-drinkers of tea and knowing the reasons for switching over different tea brands. In the later part of the questionnaire, there were demographic variables (age, gender, occupation) to understand which groups of people drink tea more or less.

\section{6: Sampling Techniques}

In this study, convenience sampling, a nonprobability sampling technique has been used to select respondents where the selection of sampling units is left primarily to the interviewer.

\subsection{1: Sampling Unit}

Survey was conducted with both male and female consumers from households (all level of adult age-group) who drink tea.

\subsection{2: Sampling Frame}

The respondents were selected from Dhaka regions. To be more specific, the areas were Azimpur, Lalbagh, Dhaka University-R/A, Dhanmondi, Mohammadpur, and Mirpur.

\subsection{3: Sample Size}

The sample size was 120 .

\section{0: PLAN OF DATA ANALYSIS}

In this study, consumer's loyalty to specific tea brand was used as dependent variable while product attributes, perceived value, superiority, availability, willingness to go to another shop for searching preferred brand, brand recall, refer to others, brand image, facility for returning product, grievance redress were used as independent variables. For the data analysis purpose, researchers used an advanced statistical procedure i.e. multiple regression (to determine the strength of relationship between the dependent variable and one or more independent variables). Moreover, cross tabulation was used to determine the percentage of male and female consumers' switching behavior to different tea brands.

\section{0: FINDINGS AND ANALYSIS}

The researcher first used regression analysis to conclude effect of different factors on consumers' loyalty level and then 
bivariate cross tabulation to find out consumption trend of female and male consumers.

\section{1: Regression Analysis}

In this study, multiple regression has been used to determine the strength of relationship between the dependent variable, consumers' loyalty, and more than one independent variables.

\subsection{1: Model Summary}

The model summary of the regression analysis is shown in the table-1. Here, the predictors are: fulfillment of desired need, taste, color, aroma, attractive package, promised quality, reasonable price, availability, willingness to search in another shop, recall the brand, superiority, refer others to purchase, return of product, complain management. The dependent variable is consumers' loyalty toward a tea brand.

Table - 1: Regression Model Summary

\begin{tabular}{|c|c|c|c|c|}
\hline Model & $\mathrm{R}$ & R Square & $\begin{array}{c}\text { Adjusted R } \\
\text { Square }\end{array}$ & $\begin{array}{c}\text { Std. Error of the } \\
\text { Estimate }\end{array}$ \\
\hline 1 & $0.859^{\text {(a) }}$ & 0.738 & 0.703 & 0.79837 \\
\hline
\end{tabular}

(a) Predictors: (Constant), Fulfill Desired Need, Attractive packaging, Likeable Color, Nice Aroma, Good Taste, Promised Quality, Reasonable Price, Availability, Search in another Shop when unavailable, Recall the brand at first, Superior Brand, Refer others to Purchase the brand, Facility to Return, Solution to Customer Complain.

\section{Source: SPSS Output}

Here, the $\mathrm{R}$ square is 0.738 , which is close to 1 , and that indicates that there is strong relationship between the consumers' loyalty toward a tea brand (dependent variable) and fulfillment of desired need, taste, color, aroma, attractive package, promised quality, reasonable price, availability, willingness to search in another shop, recall the brand, superiority, refer others to purchase, return of product, complain management (multiple independent variables).

The value of adjusted $\mathrm{R}$ square ( $\mathrm{R}$ square is adjusted for the number of independent variables and the sample size to account for diminishing return) is 0.703 which is close to $R$ square and also close to 1 . It suggests that each of the additional independent variables after adding the first independent variable makes a significant contribution in explaining the variation in the dependent variable. The value of adjusted $\mathrm{R}$ square indicates that fulfillment of desired need, taste, color, aroma, attractive package, promised quality, reasonable price, availability, willingness to search in another shop, refer others to purchase, ability to recall the brand, superiority, return of product, complain management (independent variables) accounted for $70.30 \%$ of the variation in the consumers' loyalty toward a branded tea.

\subsection{2: Significance Testing}

In this study, a test has been conducted to test the significance of the overall regression equation and specific partial regression coefficients. Table - 2 shows the level of significance of the overall regression equation:

Table - 2: Significance testing for overall regression model.

\begin{tabular}{|c|c|c|c|c|c|c|}
\hline \multicolumn{7}{|c|}{ ANOVA $^{(b)}$} \\
\hline \multirow{2}{*}{ Model } & & $\begin{array}{c}\text { Sum of } \\
\text { Squares }\end{array}$ & Df & $\begin{array}{c}\text { Mean } \\
\text { Square }\end{array}$ & F & Sig. \\
\hline \multirow{3}{*}{1} & Regression & 188.374 & 14 & 13.455 & 21.110 & $.000^{\text {(a) }}$ \\
\cline { 2 - 8 } & Residual & 66.926 & 105 & .637 & & \\
\cline { 2 - 8 } & Total & 255.300 & 119 & & & \\
\hline
\end{tabular}


(a) Predictors: (Constant), Fulfill Desired Need, Attractive packaging, Likeable Color, Nice Aroma, Good Taste, Promised Quality, Reasonable Price, Availability, Search in another Shop when unavailable, Recall the brand at first, Superior Brand, Refer others to Purchase the brand, Facility to Return, Solution to Customer Complain.

(b) Dependent Variable: Loyalty

\section{Source: SPSS Output}

From the above table it found that the significance level of the $F$ value $(0.000)$ is below $\alpha=0.05$ with an $F$ distribution. The calculated value of $F$ is 21.110 , at 14 and 105 degrees of freedom, is also greater than the table value. These indicate that independent variables have significant relationship with the dependent variable. So, the null hypothesis $\left(\mathrm{H}_{0}\right)$ that the coefficient of multiple determination in the population $\left(\mathrm{H}_{0}: \mathrm{R}^{2}\right.$ pop $=0$ ) is rejected.

Therefore, it indicates that the regression equation is significant and independent variables: (Constant), fulfillment of desired need, taste, color, aroma, attractive package, promised quality, reasonable price, availability, willingness to search in another shop, refer others to purchase, ability to recall the brand, superiority, return of product, complain management have significant relationship with the dependent variable: consumers' loyalty toward a tea brand. As the null hypothesis has been rejected, one or more population partial regression coefficients have a value other than zero. Partial regression coefficients are also tested in order to determine which specific coefficients are nonzero.

\subsection{3: Coefficients Analysis}

Table - 3 shows which independent variables (fulfillment of desired need, taste, color, aroma, attractive package, promised quality, reasonable price, availability, willingness to search in another shop, refer others to purchase, ability to recall the brand, superiority, return of product, complain management), included in the model, have significant relationship with the dependent variable (loyalty toward a specific tea brand).

Table - 3 : Significance testing for coefficients/ coefficient analysis

\begin{tabular}{|l|c|c|c|c|c|}
\hline \multicolumn{5}{|c|}{ Coefficients } \\
& \multicolumn{7}{|c|}{$\begin{array}{c}\text { (a) } \\
\text { Cn-standardized }\end{array}$} & $\begin{array}{c}\text { Standardized } \\
\text { Coefficients }\end{array}$ & t & Sig. \\
\cline { 2 - 6 } & B & $\begin{array}{c}\text { Std. } \\
\text { error }\end{array}$ & Beta & & \\
\hline (Constant) & -8.191 & 1.830 & & -4.476 & .000 \\
\hline $\begin{array}{l}\text { Fulfill one's } \\
\text { Desired Need }\end{array}$ & .833 & .152 & .807 & 5.481 & .000 \\
\hline $\begin{array}{l}\text { Attractive } \\
\text { packaging }\end{array}$ & .002 & .092 & .002 & .024 & .981 \\
\hline Likeable Color & .404 & .066 & .618 & 6.114 & .000 \\
\hline Nice Aroma & -.268 & .089 & -.228 & -3.007 & .003 \\
\hline Good Taste & 1.988 & .728 & .463 & 2.731 & .007 \\
\hline Promised Quality & 1.216 & .182 & 1.039 & 6.693 & .000 \\
\hline Reasonable Price & .521 & .089 & .598 & 5.868 & .000 \\
\hline $\begin{array}{l}\text { Available in the } \\
\text { Market }\end{array}$ & -.912 & .483 & -.264 & -1.887 & .062 \\
\hline $\begin{array}{l}\text { Search in another } \\
\text { Shop when } \\
\text { unavailable }\end{array}$ & 1.109 & .324 & .522 & 3.428 & .001 \\
\hline $\begin{array}{l}\text { Recall the brand } \\
\text { at first }\end{array}$ & -1.038 & .200 & -.656 & -5.200 & .000 \\
\hline $\begin{array}{l}\text { Perceived as } \\
\text { Superior Brand }\end{array}$ & 1.287 & .313 & 1.144 & 4.115 & .000 \\
\hline
\end{tabular}




\begin{tabular}{|l|c|c|c|c|c|}
\hline $\begin{array}{l}\text { Refer others to } \\
\text { Purchase the } \\
\text { particular brand }\end{array}$ & -.808 & .306 & -.742 & -2.635 & .010 \\
\hline Facility to Return & -.271 & .094 & -.341 & -2.896 & .005 \\
\hline $\begin{array}{l}\text { Customer } \\
\text { Complain }\end{array}$ & .130 & .055 & .170 & 2.347 & .021 \\
\hline $\begin{array}{l}\text { (a) Dependent Variable: Loyalty } \\
\text { Level of Significance } \infty=0.05\end{array}$
\end{tabular}

\section{Source: SPSS Output}

The table-3 indicates that the significance levels for fulfillment of desired need (.000), color (.000), aroma (.003), taste (.007), promised quality $(.000)$, reasonable price $(.000)$, willingness to search in another shop in case of unavailability (.001), ability to recall the brand (.000), superiority (.000), refer others to purchase (.010), return of product (.005), complain management (.021) have significant relationship with consumers' loyalty to a tea brand.

On the other hand, variables like attractive package (.981) and availability (.062) have not any or less significant relationship with the consumers' loyalty to a tea brand. From table-3, the estimated regression model can be drawn in following manner:

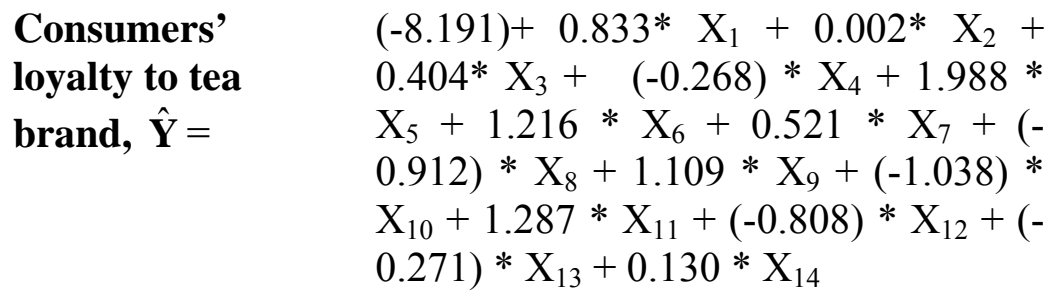

Or,

\section{Consumers' loyalty to tea brand, $\hat{\mathbf{Y}}=$}

$(-8.191)+0.833 *$ desired need $+0.002 *$ packaging $+0.404 *$ color $+(-0.268) *$ aroma $+1.988 *$ taste $+1.216 *$ quality $+0.521 *$ price $+(-0.912) *$ availability $+1.109 *$ search in another shop $+(-$ $1.038) *$ recall $+1.287 *$ superior $+(-$ $0.808) *$ refer to other $+(-0.271) *$ return product $+0.130 *$ customer complain

Therefore, these results of partial regression coefficients suggests that-

1. Product attributes like color, aroma, taste, and promised quality are important to influence the level of consumers' loyalty to a particular tea brand.

2. Factors like ability to fulfill ones desired need, reasonable price, willingness to search in another shop in case of unavailability, ability to recall the brand, superiority, refer others to purchase, return of product, complain management in proper way by marketers are important to influence the level of consumers' loyalty to a particular tea brand.

3. On the other hand, factors like attractive package and availability are less or not significant at all to the choice of ice-cream consumption.

4. All these factors like fulfillment of desired need, color, aroma, taste, promised quality, reasonable price, willingness to search in another shop in case of unavailability, ability to recall the brand, superiority, refer others to purchase, return of product, complain 
management accounted for $70.30 \%$ variation in the consumers' loyalty to a tea brand.

\section{Bivariate Cross-tabulation \& Other Interpretations}

Bivariate cross-tabulation describes two categorical variables simultaneously in a table that reflects the joint distribution of two or more variables (Malhotra, 2008, p. 469).

\section{Gender and Frequency of Consumption Cross-tabulation}

In this study, cross-tabulation has been used to show relationship between gender and their frequency or possibility of switching over different tea brands by cross classifying these two variables. For this purpose, how often consumers might switch tea brand has been categorized into three groups (Low, medium, and high). This cross-tabulation has been shown in table- 4 , in case of male and female consumers.

\section{Table - 4: Gender by Switching Possibility of tea brand cross tabulation}

\begin{tabular}{|c|c|c|c|}
\hline \multirow{2}{*}{\multicolumn{2}{|c|}{ Switching Possibility }} & \multicolumn{2}{|c|}{ Gender } \\
\hline & & \multirow{2}{*}{$\begin{array}{c}\text { Male } \\
46\end{array}$} & \multirow{2}{*}{$\begin{array}{c}\text { Female } \\
47\end{array}$} \\
\hline \multirow{2}{*}{ Low } & Count & & \\
\hline & Percentage (\%) & $82.10 \%$ & $73.40 \%$ \\
\hline \multirow{2}{*}{ Medium } & Count & 5 & 9 \\
\hline & Percentage $(\%)$ & $8.90 \%$ & $14.10 \%$ \\
\hline \multirow{2}{*}{ High } & Count & 5 & 8 \\
\hline & Percentage (\%) & $8.90 \%$ & $12.50 \%$ \\
\hline \multirow{2}{*}{ Total } & Count & 56 & 64 \\
\hline & Percentage $(\%)$ & $100.00 \%$ & $100.00 \%$ \\
\hline
\end{tabular}

Source: SPSS Output
It can be concluded from table- 4 that female consumers are more prone to switch a brand compared to male consumers (26.60\% of total female respondents have medium or high possibility to switch to other brands while only $17.80 \%$ of total male respondents have this possibility). On the other hand, male consumers of tea are found to be more loyal and sticky to a brand that fulfills their demand. In this study, researchers found that $82.10 \%$ of total male respondents have shown their interest not to switch over different brands.

\section{0: RECOMMENDATIONS AND CONCLUSIONS}

\section{9:1: Recommendations}

Tea is a beverage that people have in order to avoid tiredness and for freshness. Thus, a good cup of tea should be tuned with a fine liquor color that has excellent taste with nice aroma without having a sediment dust in the cup which brings freshness for the drinker. A marketer of tea should ensure a blend of such combination in the packets of tea to make a brand superior in terms of quality in order to ensure consumers that the brand maintains promised quality to meet their demand. Furthermore, overall quality of a brand of tea should be improved further so that consumers consider the brand as a superior brand and refer others to purchase this brand.

Marketers should increase brand awareness so that consumers can have the knowledge about their brand. Increased amount of advertising can increase awareness. Besides, giving discount, coupon, free gifts etc can increase consumer usage. Proper management of collecting consumers' feedback including customers' complains can increase tea's quality and consumer usage. Above and beyond, price is another aspect that consumers think important which should also be tied within their limit. 


\section{2: Conclusions}

In Bangladesh, likewise worldwide, tea is considered as one of the most important drinks with which people are used to start their days. It is being more popular drink with the elapse of time. Hence, this industry becomes more competitive where companies are fighting together for survival in the market. When a fierce competition exists in an industry, companies fight together in the red ocean where every single player tries to eliminate others from the competition by capturing large market share. It is possible only when a company will be able to build a strong loyal customer base. In order to build a loyal customer base, researchers found that companies need to consider injecting product attributes that ensures superiority of the brand. Product attributes like color of final tea, aroma, and taste are important to satisfy consumers' desire. However, consumers' desire is not limited only to product quality. It was also found in this study that consumers also demand for reasonable price, availability on nearby shops, facility to return the product whenever necessary, and even, and proper concentration by companies in complaint management. All these factors work together in consumers' mind to consider a brand as a superior one and only then they tend to recall a brand as a favorite one and suggest others to try for the specific brand. All these parameters are important for marketer to build a strong customer base. Furthermore, they also need to focus on male and female consumers differently to satisfy their desire. As, it was found that male consumers are more loyal in nature compared to female consumers, a marketer also needs to adopt different strategy to grasp male and female consumers in the spider net of his brand.

\section{Bibliography}

Blut M., Evanschitzky H., Verena Vogel V., and Ahlert D., (2007), "Switching Barriers in the Four-Stage Loyalty Model".

Chen P. and Hitt L. M. (2007), "Measuring Switching Costs and the Determinants of Customer Retention in Internet-Enabled Businesses: A Study of the Online Brokerage Industry".

Clarke K. (2001), "What price on loyalty when a brand switch is just a click away?"

Islam G.M.R. , Iqbal M., Quddus K.G. and Ali M. Y. (2009), "Present Status and Future Needs of Tea Industry in Bangladesh".

Kaniz J. (2009), "Purchasing and Switching Behavior of Tea Consumer: An Empirical Study".

Keller K. L. (2001), "Building Customer- Based Brand Equity: A Blueprint for Creating Strong Brands".

Keller K. L. (2008), "Strategic Brand Management- Building, Measuring, and managing Brand Equity", ( $3^{\text {rd }}$ edn.), Pearson Education Limited

Kotler P. and Armstrong G. (2008), "Principles of Marketing", (12 edn.), Pearson Education Limited

Knowles J. (2005), "In Search of a ReliableMeasure of Brand Equity".

Kuhn k. and Alpert F. (2003), “Applying Keller's Brand Equity Model in a B2B Context: Limitations and an Empirical Test".

Lopez J. P. M., Redondo Y. P. and Olivan J. S. (2008), “The Impact of Customer Relationship Characteristics on Customer Switching Behavior- Differences Between Switchers and Stayers".

Malhotra N. K. (2008), "Marketing Research - An Applied Orientation", $\left(5^{\text {th }}\right.$ edn. $)$, Pearson Education Limited 
Paich M., Peck C., and Valant J. (2000), "Modeling Customers Switching Between Brands The General Case".

Waarden L. M. (2009), "Loyalty Programs: Strategies and Practice".

Watson A., Viney H., and Schomaker P. (2002), "Consumer Attitudes to Utility Products: A Consumer Behaviour Perspective".

Wernerfel B. (1991), "Brand Loyalty and Market Equilibrium", Marketing Science, Vol. 10, No.3, pp. 229-245.

\section{Other}

SIRIUS Marketing and Social Research Limited, "Usage and Attitude Study on Tea-Findings from Qualitative Component", September 2009.

\section{Website}

'A study of market structure: brand loyalty and brand switching behaviors for durable household appliances', Retrived on October 05, 2010 from http://www.accessmylibrary.com/ article-1G1-66276101/study-market-structure-brand.html 